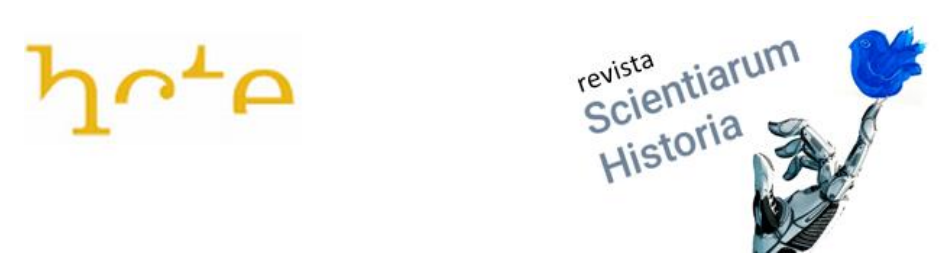

\title{
Scientific discourse modeling: a semiotic view
}

\section{Modelagem do discurso científico: uma visão semiótica}

\author{
Vinicius Claro \\ Programa de Pós-Graduação em História das Ciências e das Técnicas e Epistemologia, \\ Universidade Federal do Rio de Janeiro \\ profviniciusclaro@gmail.com
}

Recebido: 27/04/2021 Aceito: 29/04/2021 Publicado: 04/05/2021

DOI: 10.51919/revista_sh.v1i0.255

\begin{abstract}
Once introduced the semiotic concept of discourse we aim to develop a discussion about the process of constructing the scientific discourse, that is, the modeling process of scientific law declarations through linguistics texts, whereas a imposed enunciation. For that, we distinguish three basic components:1. Intention, which is a motivation, animpulse for the discourse generation; 2. Enunciation, which express the scientific text itself; and 3. Legislation, which assumes a law enunciation. All this is established in order to assume a discourse of truth, including the correspondence with mathematical proofs. So, we characterize the symbolic manipulation of self evidence empirical facts which are reflected into the enunciations by a law format.
\end{abstract}

Keywords Semiotics. Scientific law. Scientific discourse.

Resumo. Uma vez introduzido o conceito semiótico de discurso, pretendemos desenvolver uma discussão sobre o processo de construção do discurso científico, isto é, o processo de modelagem da declaração de lei científica através de textos linguísticos, enquanto uma enunciação imposta. Para tal, distinguimos três componentes básicos: 1 . Intenção, a qual é uma motivação, um impulso para geração do discurso; 2 . Enunciação, a qual expressa o texto científico propriamente dito; e 3. Legislação, a qual assume um discurso de verdade, incluindo a correspondência com a prova matemática. Assim, caracterizamos a manipulação simbólica dos fatos empíricos auto-evidentes, os quais são refletidos nas enunciações de formato de lei.

Palavras- chave: Semiótica. Lei científica. Discurso científico. 


\section{Introduction}

It is largely known that Science enunciates laws in order to assure the comprehension of Nature. As a matter of fact, modern scientists observe the Nature and edit laws about its phenomena.

How semiotics analyses the constructing of Nature law? Or else, how scientific laws are constructed inside a scientific discourse?

The point to approach is the semiotic concepts of Science discourse, considering that Semiotics analyses the manipulation of symbols. In this article we aim to self evidence empirical facts, which reflect into the scientific law enunciation by a complex semiotic process of legislation.

Therefore, we will discuss how these laws are emitted, in order to analyze the semiotic discourse generated, founded in three philosophic concepts:

- 1. Intention means a human motivation as an impulse;

- 2. Enunciation means the linguistic text formulation and

- 3. Legislation means the law characterization of this text.

We consider also the author's role as the creator of law, in a semiotic view. In order to understand the author's role, we have to discuss the difference between discourse and narrative. It is followed of another implication, that is, the debreagem effect, where the subject and the author are different instances of discourse. And finally the ritual environment: the place where the discourse occurs; specifically to enunciate the scientific law, according to its legislation, completing the semiotic concept of how scientific discourse is constructed.

\section{Sources of a Semiotics Approach}

\subsection{Two thinkers about sign}

It is necessary to begin considering Semiotics from two important authors: Charles Sanders Peirce (1839-1914, Cambridge, EUA) and Ferdinand de Saussure (1857-1914, Geneva, Switzerland), whose works are the basis of semiotics today.

While Ferdinand de Saussure was the first linguist to organize and promote Linguistics as a true Science in a modern fashion, Charles Sanders Peirce was originally a scientist of Chemistry and Logic. Although their approaches were quite different, there is a common element called sign - a fundamental step to recognize the units of significance, either humans, or as machines, particularly within Peirce's semiotic theory.

Specifically, we have signs manipulation in Science environment. Mathematics, in particular, is an instance of signs manipulation, that is, a system of logical operations, where it is only possible by writing. Morris remembers us about the role of signs systems in Science. He says:

The Science and the signs are definitively interlinked because Science not only puts man in contact with more trustworthy signs, but it also incorporates their results in systems of signs. The human civilization depends on the signs and systems of signs and the human mind is inseparable of the operation of the signs, otherwise it should not identify with this operation. (MORRIS, 1976, p. 9). 
To conclude this topic, we can say that Semiotics is the track to understand how Science is enabled to construct its own realm of knowledge, by constructing laws.

\title{
2.2. The symbolic nature of sign
}

According to Tzvetan Todorov (1977) and Umberto Eco (1984), the sign has a symbolic nature. We consider the sign as a symbolic product of mind. Primitive languages have three pillars: tropic, onomatopoeic and gestural (TODOROV, pp. 360-369).

If we detect the law's symbolic value in general, we confirm the mystifying symbolism behind a law enunciation, in particular, scientific discourse, because the intention of truth (or "will of truth", as Foucault says), becomes truth into myth. Hence, the use of sign is able to legislate because of the symbolic nature contagion over the sign.

\subsection{The symbolic aspect of the law}

The scientific law has a symbolic character while intention motivates the scientific propositions. The scientific propositions represent a model of reality accepted by scientific communities. They really exist in fact and they are originally generated in written language. As we defend, the written language is the site of hierarchy and power, since the ancient people. This aspect confirm the symbolic character of law, likewise something sacred and powerful. Wittgenstein prefers call it as figuration:

\begin{abstract}
At a first view, the proposition - in particular just as it is printed in the paper - it doesn't seem to be figuration of the reality it treats. But either the musical writing seems at a first view to be figuration of the music, and our phonetic writing (letters) are figuration of the spoken language. However, those symbolic languages show, also in the common sense, as figurations of what they represent. (WITTGENSTEIN, 1993, $\S 4.011)$.
\end{abstract}

The religious and sacred texts demonstrate that aspect in written words (linguistic signs). There is a principle of justice and a value scale. If humans do not obey to god's order, they will be punished. At this moment we observe the symbolic value of law, introduced by the imagination. It is a mechanism of structured hierarchy, where the law says what is forbidden and what is allowed. Although its orally created, the written form concedes true power.

There is a particular aspect of law. It has a hidden strength by its discourse. We mean, for example, the god's law. God's law has a symbolic meaning, and its power is assured, by his natural power. If a divinity announces a law, it reflects his power. It is important to observe that god's speech is a symbolic way of meaning. This is the symbolic manner to show how the law is powerful.

\subsection{Universal Semiosis of Law}

Why law has a universal meaning? What really is semiotic in law enunciation? To answer the first question, we have to understand the meaning of what means universal, in this context. A universal meaning is accepted by most of people, and it is understood as a common object. The universal rules of Math - Math's operations - are the basic argument of its evidences, that is, the basis of Math's law is the unequivocal evidence (results). The mathematical representation - the Math's symbols - is the most fundamental component for a scientific law. For example: a scientific law, converted in a math function, represents 
a math sentence, as an equation; but the law is emitted in linguistic signs, as the following sentence:

\title{
Water evaporates at one hundred degrees.
}

\section{Frame 1}

Following this primary logic mechanism, answering the second question above, we can infer that law is an efficient discoursing format to allow and forbid. In Science, in particular, the phenomena "are submitted" to the law discourse. Although it has a particular meaning and justification, the law scientific discourse is provided by the force of the scientific facts, by light of Empiricism. But it is not enough. The numbers involved to the scientific facts generate mathematical calculations which provide two types of proof: first unequivocal specific result, permitting previsibility; and, second, the possibility of creation of machines, that is, technology. Again, we return to symbolic values of law. This time, it is proportioned by the mathematical proofs. As we will see forward, this aspect is linked to the legislation process.

\section{Intention - Foucault and the will to truth}

Law is an authority discourse type, just because law is similar to a command. Who emits commands? Authorities do. Let's see what Boaventura Santos says:

\begin{abstract}
Nature is just extension and movement; it is passive, eternal and reversible, a mechanism whose elements can be dismantled and then related in the form of laws; it has no other quality or dignity that prevents us from unraveling its mysteries, unveiling that is not contemplative, but rather active, since it aims to know Nature in order to dominate and control it. As Bacon says, Science will make the human person «the lord and possessor of Nature». (SANTOS, 1995, p.13; emphasis added).
\end{abstract}

The discourse of authority is structured by orders. But law discourse is not a personal speech, what makes scientific laws impersonal, therefore, universal. The scientific law says the truth. Truth is the fundamental pillar for an authority realizes its power: the author's power. As Foucault says, the author is not present, even if he exists materially:

\footnotetext{
I believe there is another principle of rarefaction of a discourse, complementary to the first, to a certain extent: the author. (...) A proposition was considered as drawing even its scientific value from its author. Since the seventeenth century, this function has steadily been eroded in scientific discourse: it now functions only to give a name to a theorem, an effect, an example, a syndrome. (FOUCAULT, 1981, p. 56; emphasis added).
}

From the semiotic point of view, it is necessary to indicate that the place of meaning, or else, the symbolic meaning, is the place where the author formulates the law. We do affirm that this place of meaning is a semiotic location for a scientific discourse: it is an external view and not an ideological understanding (semantic issue), since the semioticist is most interested in formalizations.

It is clear that the scientific law enunciation is not a discovery, but a discourse about the discovery. Once a regularity of a phenomenon is discovered, the scientist is able to enunciate the law - the law only exists because of the initial conditions which allow the regularity and previsibility. So the scientific law assumes its universal character.

This is a semiotic mechanism, just because the value adopted and attributed to law is not the law itself, but the symbolic value it carries. It is a mistake thinking Nature is able to postulate laws. Laws are human creation, by a semiotic mechanism. As professor 
Boaventura remembers: "A knowledge based on the formulation of laws has as presupposed metatheoretical the idea of order and stability of the world (...)" (SANTOS, 1995, p.17).

Even the statistic mechanics in physics, scientists want to determine laws. We may consider that the previsibility is not precise and is not reduced to a unique result, but we know man has an intention for this aim: not lose the control. (SANTOS, 1995, p.15-16).

The law model choice is motivated by the intention once the scientist considers law format the best way to ensure the place for the truth. This is the way by which humankind tracked in direction to establish a human or social Science as well:

Then that Newton's prestige and the simple laws, which reduced all the complexity of the cosmic order, have converted the modern Science in the model of rationality hegemonic which gradationally it overflowed from the study of the Nature to the study of the society. Just as it was possible to discover the laws of the Nature, it would be equally possible to discover the laws of the society. (SANTOS, 1995, p.18).

We must understand this point of view, analyzing what Foucault says:

Finally, I believe that this will to truth - leading in this way on a support and an institutional distribution - tends to exert a sort of pressure and something like a power of constraint. (...) Since the nineteenth century, in a sociological, medical, and psychiatric knowledge: it is as if even the word of the law could no longer be authorized, in our society, except by a discourse of truth. (FOUCAULT, 1981, p.55; emphasis added).

Considering Foucault's words in his book The Order of Discourse, we must clear that intention is inherent to the content of discourse, before an abstract figure: the "Author". The Author is the place where the discourse is enunciated, that is, from where the environment predefines its own content, the set of ideas; we are talking about ideology as a belief system materialized into ideas expressed by language - which defines the Author's rule and performance, in his referred discourse. Therefore, the discourse content appears: the narrative, where intention followed by argumentation and linguistic competence occur. Also, the narrative is circumscribed to certain ideological system, that is intention. At this step it is not viable distinguish ideology from narrative, otherwise in a semiotic approach. Finally, we here understand narrative as the discourse content, generated by enunciation. It is a semantic issue.

\section{Enunciation procedure of law}

Greimas and Courtés began this approach by two instances: "being it like a no linguistic structure (referential), which subsumed to linguistic communication, or like a linguistic instance":

"Enunciation - If the enunciation is the place of the semiotic competence exercise, it is at the same time the instance of the subject's instauration (of the enunciation). The place where can be denominated ego hic et nunc is, before its articulation, semiotically empty and semantically (while sense deposit) too full: it is the projection (through the procedures here gathered under the name "debreagem"), outside of that instance, as much the actantes statement as of the time-space coordinates, which it constitutes the enunciation subject (...)." (GREIMAS \& COURTÉS, Enunciation entry; pp. 166-167, emphasis added). 
The "acting debreagem" (BENVENISTE, 1966) is that one there is two agents types of speaking or into the enunciation. For example, the mathematical law:

《Every divisible number for two is an equal number. 》 there are two distinguished discourse agents: the enunciator of mathematical law, that is, who dictates the enunciating rule; at the same time the logic or mathematical author is the statement producer, like Greimas \& Cortés explain:

\begin{abstract}
Beginning from the subject of the enunciation, implicit [in this case, the mathematician], but producing the statement, it can therefore, project (in the moment of the language act or of its simulacrum inside the speech), settling in the speech, be actors of the enunciation, or actors of the statement. In the first case, an enunciating debreagem is operated, in the second, a announcement debreagem. (GREIMAS \& COURTÉS; p.112, emphasis added).
\end{abstract}

So, the mathematician concedes to Mathematics the authoring prerogative. The debreagem effect reveals this transfer.

\title{
5. Legislation - the construction of a law
}

So, why does the scientist choose the law format for enunciate a referential knowledge?

We argue, at last, the applied format is semiotic. The law format, in its inner structure, as a result of legislation, reflects a repetition. If a repetitive cycle is corrupted, the law will be broken. We have to understand that law is a symbolic manner of representing repetitive cycles. Therefore, we will be able to construct previsibility, on one hand, through mathematical formulas, on other hand, observing empirically that repetition.

The use of signs expresses abstract ideas of phenomena. But also, in Science, mathematics symbols (particular signs) represent these ideas, through special terms and sentences. The math sentences are the result of a modeling process of an assembly and connected ideas in relation to an experiment - particular phenomena controlled by a scientist, who knows the initial conditions of that circumstance. The calculus are, therefore sharply defined, somehow the scientist is able to predict the results. This is possible because of a logicsymbol manipulation. At this moment, a law is enunciable - a universal truth. Just because of the unequivocal results provided by logic Math calculus, we have this possibility: enunciate a truth by formulating a law. When a law is formulated, we are able to identify a place of discourse - this place is the scientific discourse.

When we identify a scientific law, which is our semiotic interpretation? Besides the concept of enunciation above explained, under Greimas \& Courtés support, and by the Foucault's view about the place of Author, we defend that law is typically a place of authority discourse. It can only be enunciated by an authority, or better, by the representation of an authority. Law enunciations are the symbolic place of discourse which operates at the Author place. The word authority derives from author - it is important to say, etymologically.

We can see this fact in the religions environment when sacerdotal authority speaks in place of a god. The sacerdotal discourse has legal efficacy in rituals - a special ambience - where people expects to a sacred discourse, that is, a discourse by which god says laws. The religious doctrine dictates laws to men. This is a place of discourse, fundamentally a discourse of authority, where god is the author, but said by the priest's voice. This is the debreagem effect: this is a semiotic issue, since we recognize the authority's place occupied by a man instead of a god. 
But it is not only applicable to religious situations: it is largely present in juridical and scientific sceneries. In other words, the ritual place is the environment of law enunciation, for the sacerdotal discourse, juridical tribune and scientific labs as well. Foucault denotes the ritual place function:

\begin{abstract}
Ritual defines the qualification which must be possessed by individuals who speak (and who must occupy such-and-such a position and formulate such-and-such a type of statement, in the play of a dialogue, of interrogation or recitation); it defines the gestures, behavior, circumstances, and the whole set of signs which must accompany discourse. (FOUCAULT, 1981, p.62).
\end{abstract}

The enunciation must be realized in a ritual place of communication, where the speaker agent and the receptor audience are in accordance. The ritual place has a semiotic function to realize the law enunciation. It permits, therefore, the law validity and its efficacy by this kind of discourse.

We have to consider, at last, that the discourse environment, uttered in a ritual place, depends directly of a doctrine, or a theory working as a doctrine, because the narrative is the content of the discourse, according to Greimas. The discourse is the narrative realization. Again: it is the discourse content, and the discourse is the form by which the narrative happens.

\title{
6. Conclusion
}

The symbolic aspect of law, which is, in fact, a semiotic structure, permits us to understand the semiotic function in the discourse of Science context. We know that the intention is the fundamental reason to construct law - independently of the environment: be it juridical, religious or scientific, those are sites for the legislation and for the law enunciation. The ritual is the occasion when the intention of a specific discourse is pronounced, according to the ritual roles (legislation), constituted by different and concurrent signs, but where the original author is absent. What is presented really is a complex of signs, including who is speaking, that is, who possesses the discourse. The ritual place is the scenery of the law enunciation.

The law is a semiotic instrument to construct a building of knowledge, which is a semiotic structure. It also reveals the authority discourse. Intention, as Foucault called "will to truth", is the initial reason in order to understand the world and, particularly indicates the realm of Science, where the scientist produces the law enunciation, using the written signs, assembling a discourse, combining linguistic symbols with mathematical symbols.

Legislation refers to logic of repetition. If a different phrase or fact occurs, the law may lie under threat or, in other words, if a repetitive cycle (or behavior) is corrupted, the law will be broken. Without repetitive cycles mind encounters difficulties to determinate and enunciate laws. Even in statistic mechanics there are laws, but with intervals between possible results. Human mind is particularly able to construct scientific discourse just as laws may be enunciated, based in repetitive cycles and repetitive phenomena. Therefore, the law enunciation bears the scientific discourse, by which a determined ritual environment is constructed, accomplished and completed with a complex of signs.

Once a set of laws is structured and enunciated, we can see its legislation function, the basis of scientific discourse power, what may be the original intention of mind.

\section{Support}


This work was carried out with the support of the Coordenação de Aperfeiçoamento de Pessoal de Nível Superior - Brazil (CAPES) - Financing Code 001.

\section{References}

ECO, U. Tratado Geral de Semiótica. Trad. Antonio de Pádua Danesi e Gilson Cesar C. de Souza. Perspectiva. São Paulo. 2016 [1976].

ECO, U. Semiótica e Filosofia da Linguagem. Trad. Mariarosaria Fabris e José Luiz Fiori. Rev. Izidoro Blikstein. Ática. São Paulo. 1991 [1984].

BENVENISTE, É. Problèmes de Linguistic General. Gallimard, Paris. 1966.

FOUCAULT, M. The Order of Discourse. In Untying the text: A Post-Structuralist Reader. Edited by Robert Young. Routeledge \& Kegan Paul. Boston, London and Henley, 1981 (pp. 48-78).

MORRIS, C. Fundamentos da Teoria dos Signos. Trad. Milton José Pinto (PUCRJ). Ed. Eldorado, São Paulo. 1976.

SANTOS, B. S. Um Discurso sobre as Ciências. $7^{\text {a }}$ edição, pdf. Ed. Afrontamento. Porto, 1995

TODOROV, T. Teorias do Símbolo. Trad. Roberto Leal Ferreira. Ed UNESP. São Paulo, 2014.

WITTGENSTEIN, L. Tractatus Logicus-Philosophicus. Trad. Luiz Henrique Lopes dos Santos. São Paulo, EDUSP, 1993 